\title{
The Morphological Characters of the Malayan Pit Viper Calloselasma rhodostoma (Kuhl, 1824): on The Cephalic Scalation and Distribution Status in Indonesia
}

\author{
Ahmad Muammar Kadafi ${ }^{1}$, Amir Hamidy $^{2}$, Nia Kurniawan ${ }^{1 *}$ \\ ${ }^{1}$ Departemant of Biology, Faculty of Mathematics and Natural Sciences, University of Brawijaya, Malang, Indonesia \\ ${ }^{2}$ Science of Herpetology, Museum Zoologicum Bogoriense, Research Center for Biology, The Indonesian Institute of \\ Sciences, Cibinong, Indonesia
}

\begin{abstract}
The examination on variations of morphological characters among 35 specimens of Calloselasma rhodostoma (Kuhl, 1824) from four different populations in Indonesia has been completed in this study. Univariate and multivariate analyzes allowed us to recognize the clustering of four populations through morphological diagnosis. The results of the average body size (Total Length) showed that the largest male is from Kangean Island $(579.33 \mathrm{~mm}$ ), while the largest female is from Java $(841.07 \mathrm{~mm})$. Comparison of meristic analysis represented three clusters from Principal Component Analysis (PCA) which is considered to be independent population. Here we also described three types of cephalic scalation variation that called small accessories scales and their distribution in Indonesia.
\end{abstract}

Keywords: C. rhodostoma, Indonesia, Meristic, Morphometry, Viperidae.

\section{INTRODUCTION}

Vipers (Viperidae), a family of venomous snake, have been divided into two major subfamilies, Crotalinae (Pit viper) and Viperinae (Pitless viper) [1]; comprised of 242 species, and 100 of which are distributed across all continents except Australia and Antarctica [1,2]. Malayan Pit Viper (Calloselasma rhodostoma: Crotalinae) is pit viper originated from tropical Southeast Asia $[3,4]$. This species has been described by Kuhl in 1824 as Trigonocephalus rhodostoma (Boulenger, 1896), and was the sole species included in the monotypic genus. Calloselasma rodhostoma is also known as Leiolepis rhodostoma (Dumeril \& Bibron, 1854), Agkistrodon rhodostoma (De Roij, 1917), Ancistrodon annamensis (Angel, 1933), Agkistrodon annamensis (Bouret, 1936) [2], Tisiphone rhodostoma (Peters, 1862) [5].

Malayan Pit Viper is widely distributed in South East Asia, including Cambodia (Phnom Nam Lyr Mountain and Cardamom Mountain) [6], Thailand (Lop Buri, Sakon Nakhon, Korat, Chiang Mai, Nakhon Si Thammarat, Trang and Phuket) [7], Malay Peninsula (Alor Star in North Kedah), Bangnara (Patani) [8]. In Indonesia, this snake could be found in three islands; Java, Karimunjawa, and Kangean [4]. But in 1912, a single female specimen with six juveniles was

\footnotetext{
* Correspondence address:

Nia Kurniawan

Email : wawan@ub.ac.id

Address : Dept. Biology, Faculty of Mathematics and Natural Sciences, University of Brawijaya, Veteran Malang, Malang 65145.
}

collected from North Borneo, which deposited in Museum Zoologicum Bogoriense-Bogor, Indonesia (MZB 428). This species inhabits various habitat types indicating that this species is well adapted in lowland forest, plantations, shrubs, and rocky areas [4].

The morphological differences on snakes are due to several factors, including geographical variation, environmental factor (ecology, adaptation, microhabitat), and genetic $[9,10]$, such as shown in Tropidolaemus complex [11]. Studies on C. rhodostoma has been conducted related to its spatial distribution in Southeast Asia [14-18], ecological study [3,19,20], molecular systematic [21,22], diet and venom evolution [23]. The morphological character of $C$. rhodostoma is presented in cephalic scalation, dorsal scalation, ventral scalation, and body coloration [4,5,6,12,13]. However, previous studies are only limited in the comparison of snake's morphology inter-island. Therefore, the purpose of this study is to investigate the morphological variations among population of $C$. rodhostoma from Java, Karimunjawa Island, and Kangean Island.

\section{MATERIAL AND METHOD Object Study}

In this study, we examined a total of 35 preserved specimens consisted of 14 males and 21 females. All specimens were deposited in Museum Zoologicum Bogorinse (MZB-LIPI Indonesia). We divided samples into their origin (geographic consideration), to be specific, under 
3 Operational Taxonomic Unit (OTU) $[25,26]$. The population were chosen as follows: OTU $1(6 \hat{\jmath}$, 15ㅇ): Java (East Java, Central Java, West Java, and other part of Java); OTU $2(4 \hat{\jmath}, 3 \uparrow)$ : Karimunjawa Island (Legon Moto, Legon Lele); OTU $3(3 \hat{\jmath}, 3 \bigcirc)$ : Kangean Island (Paliat Island). We also examined type specimens deposited in Rijksmuseum van Natuurlijke Historie (RMNHLeiden, Netherland) and Natural History Museum (NHM-London, United Kingdom) (the list of specimens is showed in appendix I).

\section{Morphometric and Meristic Characters Measurement}

The measurement of morphometric and meristic characters in this study followed Vogel et al. [11], with modification as listed in Table 1. A total of 37 morphological characters, consisted of 19 morphometric and 18 meristic characters, were examined for each specimen. We used a slide-caliper to the nearest $0.05 \mathrm{~mm}$ for morphometric measurements, except Snout Vent Length (SVL) and Tail Length (TaL) which was measured to the nearest 1 millimeter. The counting of ventral scales, body scales, and subcaudal scales followed Dowling [23]; the terminal scute of subcaudal was excluded in this counting; while the counting of dorsal scales row followed Vogel et al. [11].
To prevent juvenile specimens be examined, we determined the size of Total Length ( $T L)$ as $400 \mathrm{~mm}$ for adult specimens. Pattern and coloration of the body were observed from fresh preserved specimens [11]. Here, we also examined all specimens for the variation on cephalic scalation identified as small accessories scale and the distribution in Indonesia. The small accessories scale that we identified as scale that touched to internasal, prefrontal, nostril and loreal scale.

\section{Data Analysis \\ Univariate analysis was conducted. Each sample was classified into three groups recognized as Java, Karimunjawa, and Kangean population as presented in Table 2. For multivariate analysis, morphometric data were classified into male and female, since snakes exhibited sexual dimorphism. Data analysis were conducted in 6 characters with bootstrap 999 for Principle Component Analysis (PCA) using PAST3 program after standardizing all characters. The standardization was done by dividing all characters with SVL and converting into percentage. The converted data was transformed to log 10 values.}

Table 1. List of Morphological Characters Used in This Study and Their Abbreviation

\begin{tabular}{ccl}
\hline Number & Abbreviation & \\
\hline Morphometric & & \\
1 & SVL & Snout-vent length \\
2 & TaL & Tail length \\
3 & TL & Total length \\
4 & HL & Head length \\
5 & HD & Head width \\
6 & ED & Eye diameter (horizontal) \\
7 & IOD & Inter orbital distance \\
8 & SnL & Snout length \\
9 & D E-nostril & Distance between the anterior eye margin and the nostril \\
10 & Tal/TL & Ratio tail length/Total length \\
11 & SnL/HL & Ratio snout length/Head length \\
12 & HL/SVL & Ratio head length/Snout-vent length \\
13 & SnL/ED & Ratio snout length/Eye diameter \\
\hline Scalation & & \\
14 & VEN & Ventral plates \\
15 & SC & Subcaudal plates \\
16 & SL & Supralabial scales \\
17 & IL & Infralabials scales \\
18 & NVEN & Number of ventral plates \\
19 & NSC & Number of subcaudal plates \\
20 & NASR & Number of dorsal scales rows behind head \\
21 & NMSR & Number of dorsal scales rows at midbody \\
22 & NPSR & Number of dorsal scales rows before vent \\
23 & TNSL & Total number of supralabial scales \\
\hline
\end{tabular}


in Indonesia (Kadafi et al)

Table 2. Summary of Morphometric Measurements of $C$. rhodostoma from Three Different Localities. Data are shown as the mean and standard deviation, followed by the range in parentheses. All measurements are shown in $\mathrm{mm}$.

\begin{tabular}{|c|c|c|c|c|c|c|}
\hline \multirow{2}{*}{$\begin{array}{l}\text { Morphological } \\
\text { Character }\end{array}$} & \multicolumn{2}{|c|}{ Java } & \multicolumn{2}{|c|}{ Karimunjawa } & \multicolumn{2}{|c|}{ Kangean } \\
\hline & $\begin{array}{c}\sigma^{7} \\
\mathrm{n}: 7\end{array}$ & $\begin{array}{c}\stackrel{9}{1} \\
\mathrm{n}: 15\end{array}$ & $\begin{array}{c}0^{7} \\
n: 4\end{array}$ & $\begin{array}{c}9 \\
n: 3\end{array}$ & $\begin{array}{c}\sigma^{\prime \prime} \\
\mathrm{n}: 3\end{array}$ & $\begin{array}{c}\stackrel{9}{1} \\
n: 3\end{array}$ \\
\hline SVL & $\begin{array}{c}446.57 \pm 23.39 \\
(399-467)\end{array}$ & $\begin{array}{c}743.87 \pm 77.69 \\
(613-892)\end{array}$ & $\begin{array}{c}409.75 \pm 30.25 \\
(382-452)\end{array}$ & $\begin{array}{c}481.67 \pm 32.08 \\
(451-515)\end{array}$ & $\begin{array}{r}465.67 \pm 9.07 \\
(459-476) \\
\end{array}$ & $\begin{array}{c}614.67 \pm 15.18 \\
(601-631)\end{array}$ \\
\hline TaL & $\begin{array}{c}109.29 \pm 7.83 \\
(96-119)\end{array}$ & $\begin{array}{c}97.20 \pm 10.10 \\
(82-116)\end{array}$ & $\begin{array}{c}89.00 \pm 7.39 \\
(82-98)\end{array}$ & $\begin{array}{c}68.33 \pm 6.66 \\
(61-74)\end{array}$ & $\begin{array}{c}113.67 \pm 4.51 \\
(109-118)\end{array}$ & $\begin{array}{c}76.00 \pm 7.81 \\
(71-85)\end{array}$ \\
\hline $\mathrm{TL}$ & $\begin{array}{c}555.71 \pm 30.20 \\
(495-568)\end{array}$ & $\begin{array}{c}841.07 \pm 85.07 \\
(704-1008)\end{array}$ & $\begin{array}{c}498.75 \pm 34.88 \\
(474-550)\end{array}$ & $\begin{array}{c}550.67 \pm 35.56 \\
(514-585)\end{array}$ & $\begin{array}{c}579.33 \pm 12.74 \\
(571-594)\end{array}$ & $\begin{array}{c}690.67 \pm 10.79 \\
(683-703)\end{array}$ \\
\hline $\mathrm{HL}$ & $\begin{array}{c}28.90 \pm 1.41 \\
(27-30.7) \\
\end{array}$ & $\begin{array}{c}45.00 \pm 3.53 \\
(39.1-52) \\
\end{array}$ & $\begin{array}{l}26.55 \pm 1.47 \\
(25.4-28.7) \\
\end{array}$ & $\begin{array}{l}28.53 \pm 4.24 \\
(23.7-31.6) \\
\end{array}$ & $\begin{array}{l}29.80 \pm 1.06 \\
(28.6-30.6) \\
\end{array}$ & $\begin{array}{l}40.10 \pm 1.22 \\
(39.3-41.5) \\
\end{array}$ \\
\hline HW & $\begin{array}{l}16.59 \pm 1.23 \\
(14.7-18.2)\end{array}$ & $\begin{array}{l}30.36 \pm 4.27 \\
(23.3-36.1)\end{array}$ & $\begin{array}{c}17.08 \pm 0.88 \\
(16.1-18)\end{array}$ & $\begin{array}{l}20.83 \pm 3.97 \\
(16.5-24.3)\end{array}$ & $\begin{array}{l}16.43 \pm 0.75 \\
(15.7-17.2)\end{array}$ & $\begin{array}{c}26.57 \pm 1.32 \\
(25.4-28)\end{array}$ \\
\hline DE-Nostril & $\begin{array}{c}5.89 \pm 0.65 \\
(5.1-7.1)\end{array}$ & $\begin{array}{c}8.62 \pm 0.60 \\
(7.6-9.9)\end{array}$ & $\begin{array}{c}5.05 \pm 0.72 \\
(4-5.6)\end{array}$ & $\begin{array}{c}5.93 \pm 1.07 \\
(4.7-6.6)\end{array}$ & $\begin{array}{c}5.60 \pm 0.20 \\
(5.4-5.8)\end{array}$ & $\begin{array}{c}7.43 \pm 0.15 \\
(7.3-7.6)\end{array}$ \\
\hline SnL & $\begin{array}{c}7.24 \pm 0.83 \\
(6.4-8.7)\end{array}$ & $\begin{array}{c}10.77 \pm 0.91 \\
(9.4-12.7)\end{array}$ & $\begin{array}{c}6.40 \pm 0.50 \\
(5.8-6.9)\end{array}$ & $\begin{array}{c}6.83 \pm 1.53 \\
(5.1-8)\end{array}$ & $\begin{array}{c}8.50 \pm 0.20 \\
(8.3-8.7)\end{array}$ & $\begin{array}{c}10.27 \pm 0.40 \\
(9.9-10.7)\end{array}$ \\
\hline$E D$ & $\begin{array}{c}3.99 \pm 0.21 \\
(3.8-4.3) \\
\end{array}$ & $\begin{array}{c}4.73 \pm 0.64 \\
(3.1-5.8) \\
\end{array}$ & $\begin{array}{c}3.98 \pm 0.22 \\
(3.7-4.2) \\
\end{array}$ & $\begin{array}{c}3.77 \pm 0.06 \\
(3.7-3.8) \\
\end{array}$ & $\begin{array}{c}4.13 \pm 0.06 \\
(4.1-4.2) \\
\end{array}$ & $\begin{array}{c}4.53 \pm 0.15 \\
(4.4-4.7) \\
\end{array}$ \\
\hline $\mathrm{TaL} / \mathrm{TL}$ & $\begin{array}{c}0.20 \pm 0.01 \\
(0.19-0.20)\end{array}$ & $\begin{array}{c}0.12 \pm 0.01 \\
(0.09-0.13)\end{array}$ & $\begin{array}{c}0.18 \pm 0.01 \\
(0.17-0.19)\end{array}$ & $\begin{array}{c}0.12 \pm 0.01 \\
(0.12-0.13)\end{array}$ & $\begin{array}{c}0.20 \pm 0.00 \\
(0.19-0.20)\end{array}$ & $\begin{array}{c}0.11 \pm 0.01 \\
(0.10-0.12)\end{array}$ \\
\hline $\mathrm{SnL} / \mathrm{HL}$ & $\begin{array}{c}0.25 \pm 0.02 \\
(0.23-0.30) \\
\end{array}$ & $\begin{array}{c}0.24 \pm 0.01 \\
(0.22-0.26) \\
\end{array}$ & $\begin{array}{c}0.24 \pm 0.02 \\
(0.22-0.26) \\
\end{array}$ & $\begin{array}{c}0.24 \pm 0.02 \\
(0.22-0.26) \\
\end{array}$ & $\begin{array}{c}0.29 \pm 0.01 \\
(0.27-0.30) \\
\end{array}$ & $\begin{array}{c}0.26 \pm 0.02 \\
(0.24-0.27) \\
\end{array}$ \\
\hline $\mathrm{HL} / \mathrm{SVL}$ & $\begin{array}{c}0.06 \pm 0.00 \\
(0.06-0.07)\end{array}$ & $\begin{array}{c}0.06 \pm 0.0 \\
(0.05-0.07)\end{array}$ & $\begin{array}{c}0.07 \pm 0.01 \\
(0.06-0.07)\end{array}$ & $\begin{array}{c}0.06 \pm 0.01 \\
(0.05-0.07)\end{array}$ & $\begin{array}{c}0.06 \pm 0.0 \\
(0.06-0.07)\end{array}$ & $\begin{array}{c}0.07 \pm 0.0 \\
(0.06-0.07)\end{array}$ \\
\hline SnL/ED & $\begin{array}{c}1.81 \pm 0.15 \\
(1.56-2.02) \\
\end{array}$ & $\begin{array}{c}2.32 \pm 0.42 \\
(1.91-3.55) \\
\end{array}$ & $\begin{array}{c}1.61 \pm 0.11 \\
(1.48-1.72) \\
\end{array}$ & $\begin{array}{c}1.82 \pm 0.43 \\
(1.34-2.16) \\
\end{array}$ & $\begin{array}{c}2.06 \pm 0.03 \\
(2.02-2.07) \\
\end{array}$ & $\begin{array}{c}2.27 \pm 0.14 \\
(2.11-2.38) \\
\end{array}$ \\
\hline
\end{tabular}

Notes: $\mathrm{n}=$ number of specimen, $\sigma^{x}=$ male specimen, $\$=$ female specimen

\section{RESULT AND DISCUSSION}

In this study, univariate statistical analysis consists of mean, standard deviation, minimum and maximum values of Java, Karimunjawa, and Kangean population as presented in Table 2 for all characters examined. The largest and smallest average males by TL character were $579.33 \mathrm{~mm}$ and $498.75 \mathrm{~mm}$ from Kangean Island and Karimunjawa Island, respectively. Whereas the largest and smallest average females were $841.07 \mathrm{~mm}$ and $573 \mathrm{~mm}$ from Java and Karimunjawa Island, respectively.

The meristic comparison that consists of the number of ventral, subcaudal, supralabial, infralabial, and dorsal scale, is presented in Table 3. According to the range of ventral scale number in males, Karimunjawa population shows higher range than Java and Kangean population. That result is in contrast to females, which shows that Karimunjawa and Kangean population is in the range of Java population. Meanwhile, according to subcaudals scale number, Kangean population has a higher range than Java and Karimunjawa population, both in male and female specimens. The range of dorsal scales number in female specimens shows that Java population has the highest range than other populations.
Several characters indicate that $C$. rhodostoma exhibits sex dimorphism (see Table 2), including SVL, HL, HW, DE-Nostril length, SnL, ratio $\mathrm{TaL} / \mathrm{TL}$, ratio $\mathrm{SnL} / \mathrm{ED}$, number of ventral scales, and subcaudal scales. The ratio of TaL/TL (males $x:$ 498.75-579.33, females $x$ : 550.67$841.07)$ shows that females have longer size than males $[27,28]$. The ratio of TaL/TL (males: $0.18-$ 0.20 , females: $0.11-0.12$ ) strongly shows that sexual dimorphism has occurred in $C$. rhodostoma. The benefits of sexual dimorphism in species with few or no parental care are related to its adaptive ability.

Generally, larger females would produce larger and higher number of offspring. Larger offspring would have higher survival rates as it is able to store more yolk for their development. In males, an individual with a smaller size will have a positive impact including enhancing their ability to find and court female. In addition, the smaller size refines the chemosensory senses, higher mobility, inconspicuous to the predator, and early maturation [29-33]. The tail length differences between males and females are due to the influence of copulatory organs (hemipenes) inside the tail, which is the size of tail length affecting male mating success [28]. 

in Indonesia (Kadafi et al)

Table 3. The Comparison of Number of Ventrals, Subcaudals, Supralabials, Infralabials, and Dorsal Scales of C. rhodostoma Specimens between Localities.

\begin{tabular}{|c|c|c|c|c|c|c|c|c|c|c|}
\hline \multirow{2}{*}{ Region } & \multicolumn{2}{|c|}{ Ventrals } & \multicolumn{2}{|c|}{ Subcaudals } & \multicolumn{2}{|c|}{ Supralabials } & \multicolumn{2}{|c|}{ Infralabials } & \multicolumn{2}{|c|}{ Dorsal Scales } \\
\hline & $\sigma^{\prime \prime}$ & 우 & $\sigma^{\pi}$ & 운 & $\sigma^{\pi}$ & ? & $\sigma^{\pi}$ & 9 & $\sigma^{x}$ & \% \\
\hline $\begin{array}{l}\text { Java } \\
\text { ơ : 7, o: } 15\end{array}$ & $144-149$ & $148-156$ & $48-54$ & $31-42$ & $7-8$ & $7-9$ & $10-12$ & $11-13$ & $22-21-17$ & $(22 / 23 / 24)-21-17$ \\
\hline $\begin{array}{l}\text { Karimunjawa } \\
\sigma^{7}: 4,9: 3\end{array}$ & $148-152$ & $150-155$ & $48-52$ & $36-39$ & $7-8$ & $7-8$ & $11-12$ & $12-13$ & $22-21-17$ & $23-21-17$ \\
\hline $\begin{array}{l}\text { Kangean } \\
\sigma^{\prime}: 3,9: 3\end{array}$ & $141-147$ & $149-152$ & $53-56$ & $38-43$ & $7-8$ & $7-8$ & 11 & $11-12$ & $22-21-17$ & $(22 / 23)-21-17$ \\
\hline
\end{tabular}

Notes: $\sigma^{\top}=$ male specimen, $\$=$ female specimen

\section{Principal Component Analysis (PCA)}

Factor loadings of the first two components from Principal Component Analysis (PCA) are presented in Table 4. Principal Component Analysis in males and females are shown in Figure 1. The two first scores of factor loadings of principal component (PC) males explain a moderate total variability. All variables show positive score loadings in the first PC, with TaL and DE-Nostril Length as the most positive loaded, in contrast with ED which is lower. The second PC shows three variables that are positively loaded, and the other three are negatively loaded. The variables of SVL and TL are the most positively loaded, in contrast to the lower load of HL. The PCA results of males' $C$. rhodostoma are shown in Figure $1 .(A)$, in this graph, plot of the two first PC show three groups: Cluster II, Cluster III, and Cluster I. Based on the locality, Cluster III is separated with Cluster II and I. However, our results show a little overlap among these two clusters (Cluster II and I). The single specimen of OTU 3 (Cluster II) is placed inside of Cluster I.

Table 4. Factor loading on the two first components extracted from the correlation matrix of 6 characters for males and females of $C$. rhodostoma

\begin{tabular}{ccccc}
\hline \multirow{2}{*}{ Characters } & \multicolumn{2}{c}{ Male } & \multicolumn{2}{c}{ Female } \\
\cline { 2 - 5 } & PC 1 & PC 2 & PC 1 & PC 2 \\
\hline SVL & 0.31562 & 0.4161 & 0.50773 & 0.049582 \\
TaL & 0.62882 & 0.24665 & 0.17259 & 0.8832 \\
TL & 0.3563 & 0.38977 & 0.45884 & 0.15948 \\
HL & 0.26703 & -0.00029 & 0.4112 & -0.3043 \\
DE-Nostril & 0.54955 & -0.74247 & 0.29035 & -0.30293 \\
ED & 0.068625 & -0.25068 & 0.2964 & 0.087715 \\
\hline Eigenvalue & & & & \\
(97.5\%) & 87.345 & 74.045 & 84.587 & 80.149 \\
\% variance & 73.525 & 16.285 & 75.166 & 12.059 \\
\hline
\end{tabular}

The first and second score factor loadings of PC females explain a moderate total variability which is similar to males. All variables show positive score loadings in the first PC with SVL and $\mathrm{HL}$ as the highest and TaL as the lowest. The second PC shows strongly structured by variables related to body characters, SVL, TaL, TL, and ED, all with positive loads. In contrast, variables related to cephalic scalation showing the highest negatively loads are $\mathrm{HL}$ and DE-Nostril Length. As in males graph (Fig. $1 \mathrm{~B}$ ), the plot of the two first PC show 3 groups: Cluster II, Cluster I, and Cluster III. Cluster II and Cluster I were separated independently among Cluster III. Cluster I and III are showed close than Cluster II.

The PCA results in males and females (Fig 1. A and $B$, respectively), show in both cases the occurrence of three clusters of plots, identified as Cluster I to III on the graph. According to the OTUs defined above, these clusters are generated by specimens according to the following scheme. These specimens are discussed below:

$$
\begin{array}{ll}
\text { Cluster I } & \text { : OTU } 1 \text { (Java population) } \\
\text { Cluster II } & \text { : OTU } 2 \text { (Karimunjawa population) } \\
\text { Cluster III } & \text { : OTU } 3 \text { (Kangean population) }
\end{array}
$$
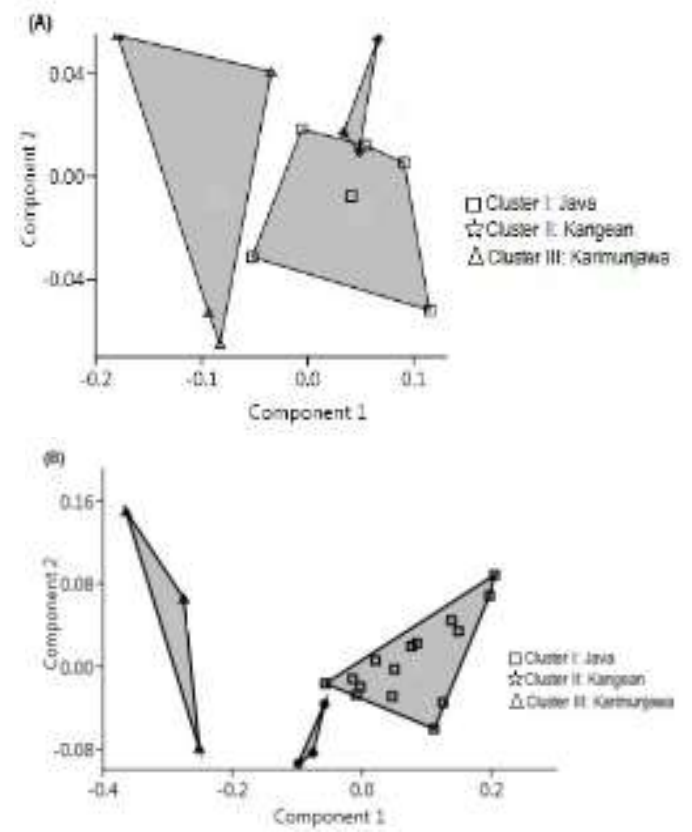

Figure 1. Plot of component 1 (PC1) versus component 2 (PC2) for the principal component analysis of males and females in three populations of $C$. rhodostoma. (A) Males; (B) Females. 


\section{Description Specimen of $\boldsymbol{C}$. rhodostoma}

The maximal total length among our samples is $1008 \mathrm{~mm}$ (SVL $892 \mathrm{~mm}$, TaL $116 \mathrm{~mm}$ ) for a female specimen from Java (Bogor, West Java) (MZB Oph 3861) and brown. Mouth is white with black dots distributed evenly. The forehead is dark brown with white stripes on both edges from the snout to the neck. The tail is slender than the body and short, can be distinguished clearly from body parts. The tail coloration on the juvenile is yellowish. The eye is small size with oval-shaped pupils (vertical).

Dorsal Scales: males specimens 22-21-17, females specimens $(22 / 23 / 24) \quad(23$ in 2 specimens, 24 in 2 specimens)-21-17, with smooth scales both in males and females. Ventral scales: VEN (1-2 paraventrals) males: 141-152, females: 148-156; with SC: 48-56 and 31-43 respectively and all paired, entire anal shield. Cephalic scalation: single rostral and visible from above, 2 Internasal contact to nostril, 2 prefrontal touching the loreal pit, single frontal, 2 supraocular above the eye, 2 parietal contact with temporal scale. Supralabial 7-8 in males, 7-9 in females with $3^{\text {rd }}, 4^{\text {th }}$, contact with the eye. Infralabial 10-12 in males, and 11-13 in females. The number of the dark brown series triangular pattern on dorsal is 19-31 [5].

\section{Head Scalation}

Based on the variation of head scalation, we found a small accessory scales (Fig. 2). A small accessory scale is a small scale bordered by internasal, prefrontal, nostril, and loreal scale. Variation on the presence or absent of a small accessory scale revealed three different types in C. rhodostoma that can be described as follows (Table 5):

1. Type 1: a small accessory scale is absent on both sides of head scalation.

2. Type 2: a small accessory scale is presence on both sides of head scalation.

3. Type 3: a small accessory scale is presence on the right side of head scalation.

In the small accessories scales, we found Type 1 as many as 44 individuals, 5 individuals for Type 2 , and Type 3 as many as 5 individuals. Figure 3 showed the distribution of $C$. rhodostoma based on the variation of the accessory scales type.
Type 1 has the most widespread distribution that was found in Thailand, Malaysia, Sumatra, Java, Karimunjawa Island, Kangean Island, and Kalimantan. Type 2 was distributed on Kalimantan and Java islands, while type 3 was only distributed in Java Island.

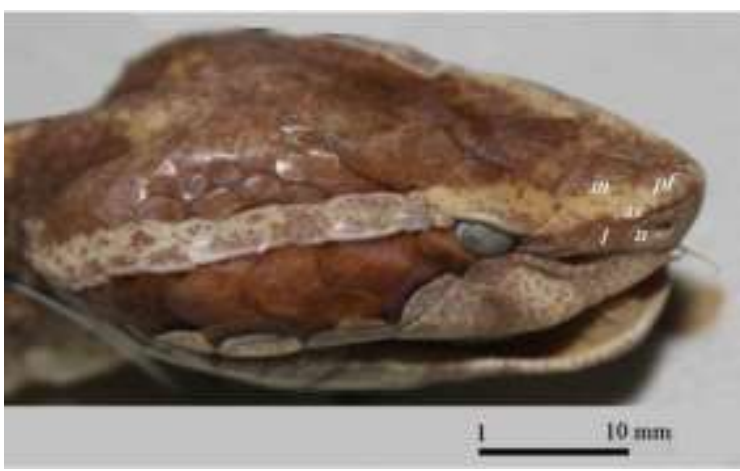

Figure 2. Head scalation of specimen of Calloselasma rhodostoma (MZB 470) from Bogor, West Java, showing the position of a small accessory scale directly adjacent to four other scales (as: accessory scale, in: internasal, pf: prefrontal, l: loreal, n: nasal).

The different variation on head scalation of $C$. rhodostoma may be affected by the snake's adaptation process with its ecological environment. Various habitats resulted in a variety of adaptation processes that lead to morphological differences in $C$. rhodostoma. The same location with different ecological conditions is also able to result in different ecogenesis processes [34]. In this research, several types of accessories scales were found in Java Island. However, the variation represented different geographical region for example Type 2 was found only in West Java, while Type 1 and Type 3 were found in Central Java and East Java.

\section{CONCLUSION}

Morphological variation in chepalic scalation, including three types of small accessories scale between population of $C$. rhodostoma in Java, Karimunjawa, Kangean Island can be used as one of the supporting data to determine the taxonomic status of the species. However, this finding needs to be tested using molecular studies for a further determination on the taxonomic status of these populations. 
Table 5. Three types of small accessories scale of C. rhodostoma in Indonesia

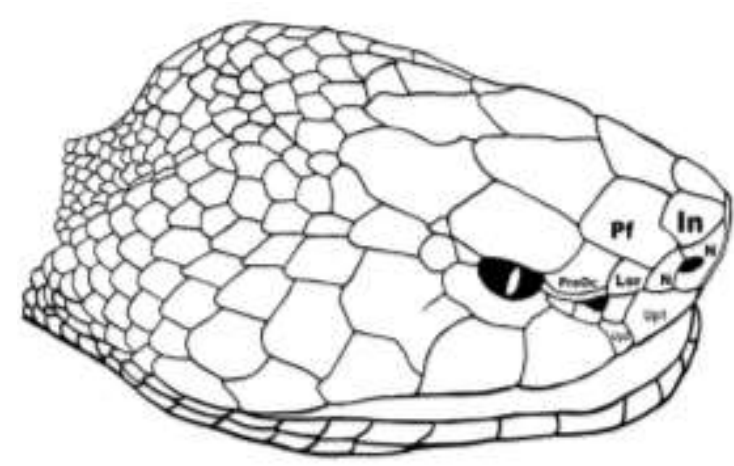

A.

Type 1. Cephalic scalation shows the absence of small accessories scales on both sides of the head. (A). Right side of head, (B). Right side of head, (In: Internasal, Pf: Prefrontal: Up1: Upperlabial ke-1, N: nostril, Lor: Loreal, PreOc: Preocular.

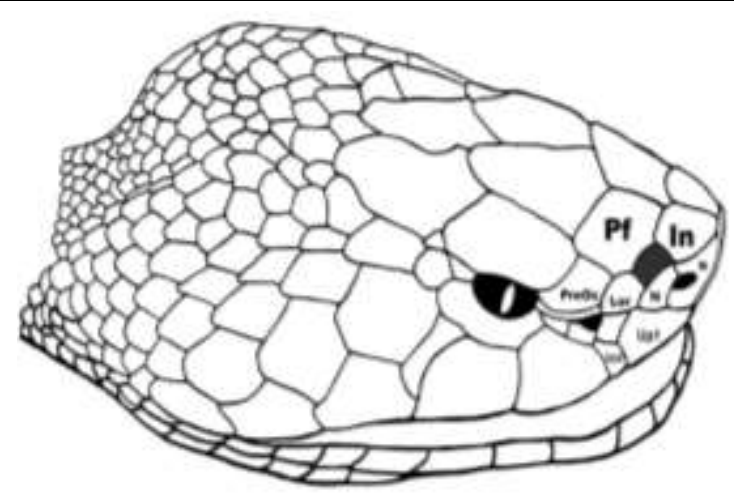

C.

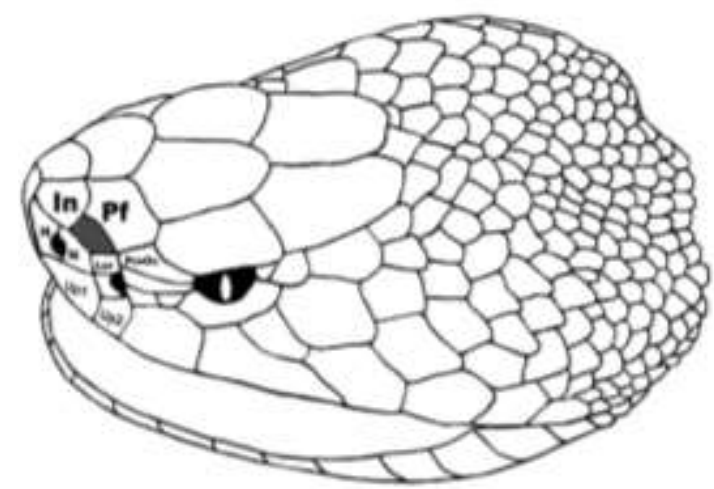

D.

Type 2. Cephalic scalation shows the presence of small accessories scales on both sides of the head. (A). Right side of head, (B). Right side of head, (In: Internasal, Pf: Prefrontal: Up1: Upperlabial ke-1, N: nostril, Lor: Loreal, PreOc: Preocular.

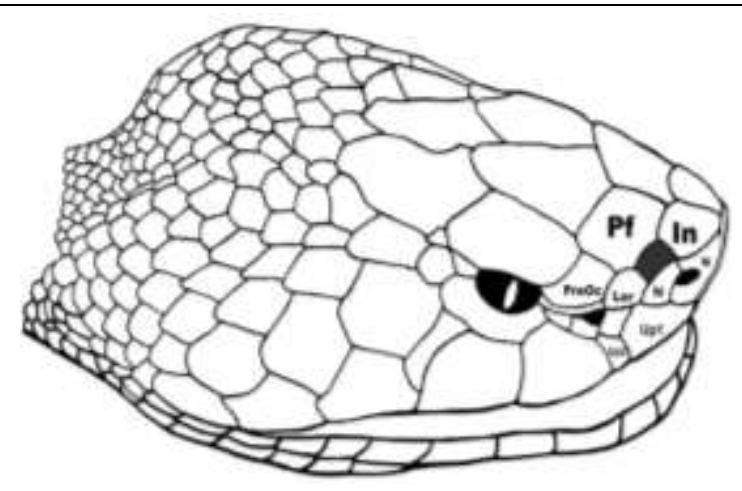

E.

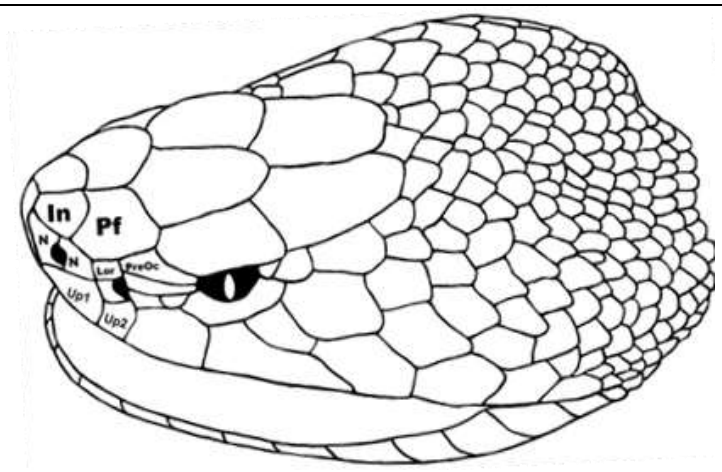

F.

Type 3. Cephalic scalation shows the presence of small accessories scales on right sides of the head. (A). Right side of head, (B). Right side of head, (In: Internasal, Pf: Prefrontal: Up1: Upperlabial ke-1, N: nostril, Lor: Loreal, PreOc: Preocular. 


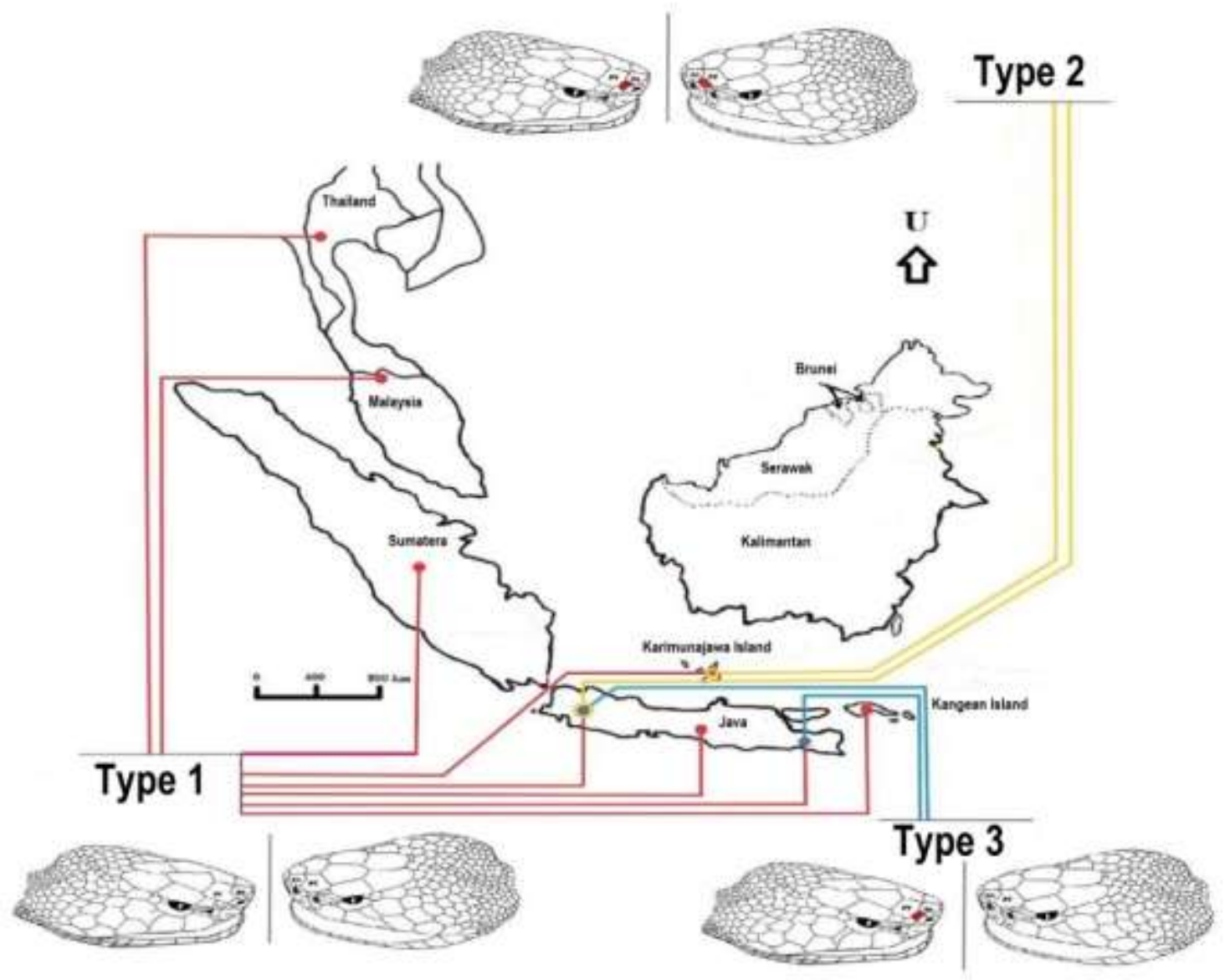

Figure 3. Relative Amount of Pro-inflammatory Cytokines in Experimental Mice after 24 Days of Treatment.

\section{REFERENCES}

[1] Wüster, W., L. Peppin, C.E. Pook, D.E. Walker. 2008. A nesting of vipers: Phylogeny and historical biogeography of the Viperidae (Squamata: Serpentes). Mol. Phylogenet. Evol. 49. 445-459.

[2] Uetz, P., J. Hallermann. 2018. Crotalinae and Viperinae. Available at: http://www.reptile-database.org.

[3] Hill III, J.G., L. Chanhome, T. Artchawakom, K. Thirakhupt, H.K. Voris. 2006. Nest attendance by a female Malayan Pit Viper (Calloselasma rhodostoma) in Northeast Thailand. Nat. Hist. J. Chulalongkorn Univ. 6(2). 57-66.

[4] Das, I. 2010. Reptiles of South-East Asia. New Holland Publisher. London.

[5] Boulenger, G.A. 1896. Catalogue of the snakes in the British Museum, Vol. 3. London (Taylor \& Francis), xiv $+727 \mathrm{pp}$

[6] Stuart, B.L., D.A. Emmett. 2006. A collection of amphibians and reptiles from the Cardamom Mountains, Southwestern Cambodia. Fieldiana Zool. N.S. (109). 1-27.
[7] Taylor, E.H. 1965. The serpents of Thailand and adjacent waters. Univ. Kansas Sci. Bull. 45(9). 609-1096.

[8] Sworder, G.H. 1933. Notes on some reptiles from the Malay Peninsula. Bull. Raffl. Mus. 8. 101-105.

[9] Mebert, K. 2011. Geographic variation of morphological characters in the Dice Snake (Natrix tessellata). MERTENSIELLA. 18. 1119.

[10] Hallgrímsson, B., B.K. Hall. 2011. Variation: a central concept in biology. Elsevier Academic Press. California, USA.

[11] Vogel, G., P. David, M. Lutz, J. van Rooijen, N. Vidal. 2007. Revision of the Tropidolaemus wagleri-complex (Serpentes: Viperidae: Crotalinae). I. Definition of included taxa and redescription of Tropidolaemus wagleri (Boie, 1827). Zootaxa. 1644. 1-40.

[12] Boie, F. 1827. Bemerkungenüber merrem's versucheines systems der Amphibien, 1. Lieferung: Ophidier. Isis van Oken. 20. 508566. 
[13] Orlov, N., N. Ananjeva, R. Khalikov. 2002. Natural history of pitvipers in eastern and Southeastern Asia. In: Schuett, G.W., M. Höggren, M.E. Douglas, H.W. Greene (Eds). Biology of the Vipers. Eagle Mountain Publishing, LC. 345-359.

[14] de Rooij, N.DE. 1917. The reptiles of the Indo-Australian archipelago. II. Ophidia. Leiden (E. J. Brill), xiv + $334 \mathrm{~S}$.

[15] Cox, M.J., Van Dijk, P. Paul, J. Nabhitabhata, K. Thirakhupt, 1998. A photographic guide to snakes and other reptiles of Peninsular Malaysia, Singapore and Thailand. Ralph Curtis Publishing.

[16] Chan-ard, T., W. Grossmann, A. Gumprecht, K.D. Schulz. 1999. Amphibians and reptiles of peninsular Malaysia and Thailand - an illustrated checklist [bilingual English and German]. Bushmaster Publications, Würselen, Gemany. Book Review in: Russ. J Herp. 7. 87.

[17] Grismer, L.L., T. Neang, T. Chav, J.L. Grismer. 2008. Checklist of the amphibians and reptiles of the Cardamom region of Southwestern Cambodia. Cambodian J. Nat. Hist. 2008(1). 12-28.

[18] Das, I. 2012. A naturalist's guide to the snakes of South-East Asia Malaysia, Singapore, Thailand, Myanmar, Borneo, Sumatra, Java and Bali. John Beaufoy Publishing. United Kingdom.

[19] Daltry, J.C., W. Wuster, S.T. Roger. 1998. Intraspecific variation in the feeding ecology of the Crotalinae snake Calloselasma rhodostoma in Southeast Asia. J. Herpetol. 32(2). 198-205.

[20] Daltry, J.C., T. Ross, R.S. Thorpe, W. Wuster. 1998. Evidence that humidity influences snake activity patterns: a field study of the Malayan pit viper Calloselasma rhodostoma. Ecography. 21. 25-34.

[21] Parkinson, C.L. 1999. Molecular systematic and biogeographical history of Pitvipers as determined by mitochondrial ribosomal DNA sequences. Copeia. 3. 576-586.

[22] Malhotra, A., R.S. Thorpe. 2000. A phylogeny of the Trimeresurus group of Pit Vipers: new evidence from a mitochondrial gene tree. Mol. Phylogenet. Evol. 16(2). 199-211.

[23] Daltry, J.C., W. Wuster, R.S. Thorpe. 1996. Diet and snake venomvolution. Nature. 379. 537-540.

[24] Dowling, H.G. 1951. A proposed standard system of counting ventrals in snakes. Brit. J. Herpetol. 1(5). 97-99.

[25] Wüster, W. 1992. Cobras and other herps in South-east Asia. Brit. Herpetol. Soc. Bull. 39. 19-25.

[26] Vogel, G. P. David, O.S.G. Pauwels. 2004. A review of morphological variation in Trimeresurus popeiorum (Serpentes: Viperidae: Crotalinae), with the description of two new species. Zootaxa. 727. 1-63.

[27] Rivas, J.A., G.M. Burghardt. 2001. Forum understanding sexual size dimorpism in snakes: wearing the snake's shoes. Anim. Behav. 62. F1-F6.

[28] Shine R., M.M. Olsson, I.T. Moore, M.P. Le Master, R.T. Mason. 1999. Why do male snakes have longer tails than females? Proc. R. Soc. Lond. B. 266. 2147-2151.

[29] Ford, N.B., Seigel, R.A. 1989. Relationships among body size, clutch size, and egg size in three species of oviparous snakes. Herpetologica. 45. 75-83.

[30] Duvall, D., G.W. Schuett, S.J. Arnold. 1993. Ecology and evolution of snake mating systems. In: Seigel, R.A., J.T. Collins (Eds). Snakes, Ecology and Behavior. New York:McGraw-Hill. 165-200.

[31] Madsen, T., R.G. Shine, J. Loman, T. Hakansson. 1993. Determinants of mating success in male adders, Vipera berus. Anim. Behav. 45. 491-499

[32] Shine, R.G. 1993. Sexual dimorphism in snakes. In: Seigel, R.A., J.T. Collins (Eds). Snakes, Ecology and Behavior. NewYork: McGraw-Hill. 49-86.

[33] Andersson, M. 1994. Sexual selection. Princeton University Press. Princeton, New Jersey.

[34] Hamidy, A. 2007. Head scalation in Naja sputatrix BOIE, 1827 - discussion on the presence of a small accessory scale. Hamadryad. 31(2). 361-365. 
APPENDIX I. Specimens material used for examine of $C$. rhodostomafrom Indonesia and sorroundings area

Java: RMNH. 1510 - Holotype of C. rhodostoma; NHM. 66.8.14.316; ZMA. RENA. 13844, 21576; RMNH.10134, 1509; BMNH. 44.2.22.47. Banten. Pandeglang: MZB. 3759 (382), 3760 (384), 3081; Tanggerang: MZB. 27766; Serang: MZB. 2125. West Java. Cimahi: MZB. 898; Cibinong: MZB. 4438; Bogor: MZB. 470, 452, 1229, 3861, 451; Lebak: ZMA. RENA. 21575; Ujung Kulon: MZB. 3818. Central Java. MZB. 4539;Karimunjawa: MZB. 432, 3017, 3047 (289), 3132 (203), 1109, 3133 (215), 3134 (216).East Java. Surabaya: MZB. 1228, Kangean Island: MZB. 3802 (2758), 3799
(2962), 3800 (2963), 3801 (2759); Malang: RMNH. RENA. 10319a, 10319b, MZB. 942; Kediri: NHM. 1885.12.31.31. Sumatera. ZMA. RENA. 21576. Thailand. NHM. 1937.2.1.13.

APPENDIX II. Museum label abbreviations. MZB: label of collection for Museum Zoologicum Bogoriense, Cibinong, Indonesia; NHM: Natural History Museum, London, United Kingdom (BMNH: British Museum and Natural History); RMNH.RENA: label of reptiles and amphibians collection for Naturalis Biodiversity Center, Leiden, Netherlands (formerly RMNH: The Rijksmuseum van Natuurlijke Historie); ZMA.RENA: label of zoology collection for Zoological Museum Amsterdam, Netherlands 